\title{
UPAYA PENCEGAHAN PEMUTUSAN HUBUNGAN KERJA PEKERJA DI SEKTOR FORMAL KARENA KEADAAN MEMAKSA PANDEMI COVID-19
}

\author{
Steven Suprantio \\ Senior Associate, Law Firm Santoso Wiryanto Ardiwinata \\ email: steven.suprantio@gmail.com
}

disampaikan 22/5/2020 - di-review 10/9/2020 - diterima 20/6/2021

DOI: $10.25123 /$ vej.v7i1.3921

\begin{abstract}
The business world everywhere including those in Indonesia cannot but felt the brunt of economic slowdown caused by the public health emergency (the COVID 19 pandemic). Quite a few national and local businesses have had to close their operation and lay off all its employees. Although the consensus between the government, workers (individuals and unions) as well as employers is to prevent and avoid termination of employment at all costs, the Law No. 11 of 2020, re. Job Creation allows massive dismissal of employees due to economic necessity or state of emergency. This article shall critically examine how the prevailing law, Law No. 11 of 2020 re. Job Creation regulates termination of employment in case of state of emergency.
\end{abstract}

Keywords:

termination of employment, force majeure, public health emergency, COVID 19

\begin{abstract}
Abstrak
Dunia usaha di manapun termasuk di Indonesia merasakan dampak ekonomi dari kedaruratan kesehatan masyarakat yang disebabkan pandemic COVID 19. Salah satu dampak terburuk adalah keputusan untuk menutup perusahaan dan memutus hubungan kerja dengan semua pekerja. Sekalipun sebagai suatu kebijakan umum, pemutusan hubungan kerja dipandang sebagai hal yang seharusnya dihindari dan dicegah, perusahaan yang menutup usaha karena dampak negative pandemic diperkenankan melakukannya atas dasar adanya keadaan memaksa. Khususnya UU No. 11 tahun 2020 tentang Cipta Kerja mengatur peluang bagi perusahaan untuk melakukan pemutusan hubungan kerja tersebut. Tulisan ini akan menelaah secara kritis pengaturan pemutusan hubungan kerja dalam keadaan memaksa ini
\end{abstract}

Kata Kunci:

PHK, corona, keadaan memaksa, kedaruratan kesehatan masyarakat

\section{Pendahuluan}

Penyebaran virus corona di Indonesia yang masif telah memberikan dampak negatif pada dunia usaha dan perdagangan. Menurut The World Economic Forum $^{1}$, Indonesia diperkirakan terkena dampak sebesar USD 312.000.000 akibat penyebaran virus corona ini. Sedangkan menurut Menteri Keuangan, Sri Mulyani

1 Natalie Blyth, How Companies Can Build Resilience Against Pandemics, https://www.weforum.org/agenda/2020/04/how-companies-build-resilience-againstpandemics/, diakses 20 Mei, 2020. 
Indrawati2, "virus corona jauh lebih kompleks dari 2008-2009 karena mengancam manusia, mematahkan seluruh fondasi ekonomi di seluruh negara dan gejolak di pasar modal yang tidak ada jangkar," papar Sri Mulyani." Pendapat ini sangat beralasan, pandemi virus corona telah menimbulkan dampak yang besar pada ekonomi, pelaksanaan hubungan kerja, mempengaruhi penyediaan barang dan jasa juga konsumsi dan investasi di Indonesia bahkan di seluruh dunia.

Hal senada dituliskan oleh Bank Indonesia ${ }^{3}$, dalam Laporan Perekonomian Indonesia 2019 yang diterbitkan pada 30 Maret 2020: "penyebaran COVID-19 di banyak negara, termasuk di Indonesia, akan menurunkan kinerja perekonomian dari sektor pariwisata, perdagangan, manufaktur, dan kemudian merambat sektor lainnya Kondisi ini akan menurunkan kinerja ekspor barang dan jasa, serta mendorong konsumsi swasta dan investasi menjadi lebih rendah."

Kondisi perekonomian yang memburuk tak dapat dielakkan telah memicu gelombang pemutusan hubungan kerja di Indonesia. Menurut Menteri Ketenagakerjaan, Ida Fauziah hingga 7 April 2020 total jumlah perusahaan yang merumahkan pekerja dan melakukan pemutusan hubungan kerja (selanjutnya disebut PHK) adalah sebanyak 74.430 perusahaan dan 1.200.031 Pekerja/buruh.

Bagan 1: Total Jumlah Perusahaan Yang Merumahkan Pekerja dan Melakukan PHK

\begin{tabular}{clcc}
\hline No. & \multicolumn{1}{c}{ Status } & Jumlah Perusahaan & Jumlah Pekerja/buruh \\
\hline 1. & Pekerja formal dirumahkan & 17.224 & 873.090 \\
\hline 2. & Pekerja formal diputus hubungan kerja & 22.753 & 137.489 \\
\hline 3. & $\begin{array}{l}\text { Pekerja informal dirumahkan atau } \\
\text { diputus hubungan kerja }\end{array}$ & 34.453 & 189.452 \\
\hline \multicolumn{2}{c}{ Jumlah Total } & $\mathbf{7 4 . 4 3 0}$ & $\mathbf{1 . 2 0 0 . 0 3 1}$ \\
\hline
\end{tabular}

Sumber: Data dari CNBC Indonesia ${ }^{4}$

2 CNNIndonesia.com, Sri Mulyani Sebut Dampak Virus Corona Melebihi Krisis 1998, https://www.cnnindonesia.com/ekonomi/20200406193647-532-490944/sri-mulyani-sebutdampak-virus-corona-melebihi-krisis-1998, diakses 16 April, 2020.

3 Bank Indonesia, Laporan Perekonomian Indonesia 2019, https://www.bi.go.id/en/ruangmedia/info-terbaru/Pages/Buku-Laporan-Perekonomian-2019-Sinergi-Kunci-Utama-MenjagaPerekonomian-di-Tengah-Pandemi-Covid-19.aspx, diakses pada 16 April, 2020.

4 CNBCIndonesia.com, Corona Makan Korban: 1,2 Juta Pekerja Kena PHK dan Dirumahkan, https://www.cnbcindonesia.com/news/20200409190039-16-151007/corona-makankorban-12-juta-pekerja-kena-phk-dan-dirumahkan, diakses 20 Mei, 2020. 
Data di atas kemungkinan akan terus bertambah, International Labour Organization $^{5}$ (selanjutnya disebut ILO) memperkirakan pandemi virus corona akan memusnahkan 6,7 persen jam kerja secara global dalam kuartal kedua tahun 2020 - yang setara dengan 195 juta pekerja penuh waktu, untuk wilayah Asia dan Pasifik diperkirakan mencapai 7,2 persen atau 125 juta pekerja penuh waktu.

Ditengah kondisi yang penuh ketidakpastian kapan pandemi virus corona berakhir, kondisi ekonomi yang cenderung memburuk, pengusaha mungkin memilih opsi PHK dengan alasan keadaan memaksa (force majeure) sesuai dengan ketentuan Undang-Undang R.I, No 13 Tahun 2003, Ketenagakerjaan, L.N.R.I Tahun 2003 (Selanjutnya disebut UU Ketenagakerjaan), sebagaimana terakhir kali diubah dengan Undang-Undang RI, No 11 Tahun 2020, Cipta Kerja, L.N.R.I Tahun 2020, Pasal 154A Ayat (1) Huruf d (Selanjutnya disebut UU Cipta Kerja), yang berbunyi Pemutusan Hubungan Kerja dapat terjadi karena alasan perusahaan tutup yang disebabkan keadaan memaksa (force majeur). Tujuannya untuk mempertahankan kelangsungan usaha dan menghindari dampak yang jauh lebih besar lagi.

Meskipun langkah yang diambil perusahaan dapat dipahami, menurut penulis perlu dianalisa lebih lanjut apakah pandemi virus corona merupakan kondisi keadaan memaksa yang dapat dijadikan alasan untuk melakukan PHK. UU Ketenagakerjaan dan UU Cipta Kerja sendiri tidak memberikan penjelasan ataupun batasan dari keadaan memaksa. Adanya kekosongan hukum ini dapat menyebabkan ketidakpastian hukum dan ketidakadilan. Sebaliknya, menurut ketentuan Pasal 151 ayat (1) UU Cipta Kerja, baik pengusaha, Pekerja/buruh, serikat pekerja/serikat buruh dan pemerintah harus mengusahakan jangan terjadi PHK. Sehingga apakah terdapat alternatif yang dapat diambil oleh pengusaha, Pekerja/buruh, dan pemerintah untuk mencegah terjadinya PHK karena adanya pandemi virus corona. Dalam tulisan ini penulis akan berupaya menjawab kedua pertanyaan ini.

5 ILO,Covid 19: Mendorong kebutuhan ekonomi dan ketenagakerjaan ILO: COVID-19 Sebabkan Kehilangan Besar dalam Jam Kerja dan Pekerjaan, https://www.ilo.org/jakarta/info/public/pr/WCMS_741127/lang--en/index.htm, diakses 20 Mei, 2020. 
Penulis membatasi tulisan ini pada pekerja yang bekerja di sektor formal sebagaimana diatur dalam UU Ketenagakerjaan dan UU Cipta Kerja, karena menurut penulis pembahasan mengenai pekerja di sektor informal berada dalam keadaan yang (mungkin) lebih rentan dan membutuhkan analisa secara khusus dengan menggunakan pisau analisa yang berbeda pula.

\section{Pembahasan}

\section{Penetapan Virus Corona Sebagai Penyakit Yang Menimbulkan Kedaruratan Kesehatan Masyarakat}

Penambahan orang yang terinfeksi virus corona secara masif di Indonesia, menyebabkan diterbitkannya Keputusan Presiden R.I. No. 11 Tahun 2020, Penetapan Kedaruratan Kesehatan Masyarakat Corona Virus Disease 2019 (COVID-19) yang menetapkan virus corona sebagai penyakit yang menimbulkan kedaruratan kesehatan masyarakat dan menetapkan Indonesia berada dalam keadaan kedaruratan kesehatan masyarakat. Pada saat tulisan dibuat, pada tanggal 19 Mei 2020 telah terdapat 18.496 jiwa orang yang ter konfirmasi positif virus corona 6 .

Kondisi kedaruratan kesehatan masyarakat menurut ketentuan UndangUndang R.I, Nomor 6 Tahun 2018, Kekarantinaan Kesehatan, L.N.R.I. Tahun 2018 Pasal 1 Angka 2 (selanjutnya disebut UU Kekarantinaan Kesehatan), adalah “Kejadian kesehatan masyarakat yang bersifat luar biasa dengan ditandai penyebaran penyakit menular dan/atau kejadian yang disebabkan oleh radiasi nuklir, pencemaran biologi, kontaminasi kimia, bioterorisme, dan pangan yang menimbulkan bahaya kesehatan dan berpotensi menyebar lintas wilayah atau lintas negara."

Sebagai respons dari kedaruratan kesehatan masyarakat, dilakukan karantina rumah atau karantina wilayah atau karantina rumah sakit atau pembatasan sosial berskala besar. Menurut Pasal 1 Angka 11 UU Kekarantinaan Kesehatan, pembatasan sosial berskala besar (selanjutnya disebut PSBB) adalah

\footnotetext{
6 Gugus Tugas Percepatan Penanganan COVID19, Peta Sebaran, https://www.covid19.go.id/situasi-virus-corona/, diakses 19 Mei, 2020
} 
pembatasan kegiatan tertentu penduduk dalam suatu wilayah yang diduga terinfeksi penyakit dan/atau terkontaminasi sedemikian rupa untuk mencegah kemungkinan penyebaran penyakit atau kontaminasi. Tujuannya adalah mencegah meluasnya penyebaran penyakit kedaruratan kesehatan masyarakat (virus corona) yang sedang terjadi antar orang di suatu wilayah tertentu.

Menurut Peraturan Pemerintah R.I. Nomor 21 Tahun 2020, Pembatasan Sosial Berskala Besar Dalam Rangka Percepatan Penanganan Corona Virus Disease 2019 (Covid-19), L.N.R.I 2020 (selanjutnya disebut PP PSBB) Pasal 3 jo. Peraturan Menteri Kesehatan R.I. No. 9 Tahun 2020, Pedoman Pembatasan Sosial Berskala Besar Dalam Rangka Percepatan Penanganan Corona Virus Disease 2019 (COVID19) (selanjutnya disebut Permenkes Pedoman PSBB), B.N.R.I. 2020 Pasal 2, Pemberlakuan PSBB diusulkan oleh Gubernur/Walikota/Bupati dan harus mendapatkan persetujuan dari Menteri Kesehatan dengan mempergunakan kriteria berupa (1) jumlah kasus dan/atau jumlah kematian akibat penyakit meningkat dan menyebar secara signifikan dan cepat ke beberapa wilayah; dan (2) terdapat kaitan epidemilogis.

Saat tulisan ini disusun telah terdapat daerah-daerah yang ditetapkan PSBB, diantaranya yaitu Provinsi DKI Jakarta, Kota Bogor, Kabupaten Bogor, Kota Depok, Kota Bekasi, Kabupaten Bekasi, Kota Tangerang, dan Kota Pekanbaru ${ }^{7}$. Dalam Pasal 4 Ayat (1) PP PSBB Jo. Pasal 13 ayat (1) Permenkes Pedoman PSBB diatur kegiatan-kegiatan yang dibatasi pada saat pemberlakuan PSBB salah satunya adalah peliburan tempat kerja. Peliburan tempat kerja berarti pembatasan proses bekerja di tempat kerja dan menggantinya dengan proses bekerja di rumah/tempat tinggal, untuk menjaga produktivitas/kinerja pekerja.

Dengan kata lain peliburan tempat kerja tidak menyebabkan pengusaha dan/atau Pekerja atau buruh sama sekali tidak dapat melakukan kewajiban dan haknya. Kewajiban dan haknya tetap dapat dilakukan, hanya dibatasi dengan adanya "peliburan tempat kerja". Terhadap jenis-jenis usaha yang ditetapkan PSBB

7 CNBC Indonesia, Ini Daerah Asal \& Tujuan yang Terkunci untuk Aktivitas Mudik https://www.cnbcindonesia.com/news/20200424200534-4-154348/ini-daerah-asal-tujuanyang-terkunci-untuk-aktivitas-mudikterakhir, diakses 5 Mei, 2020. 
juga terdapat pengecualian misalnya perusahaan yang bergerak di bidang obatobatan, logistik dan transportasi, kegiatan dilakukan dengan tetap memperhatikan kebijakan physical distancing. Sedangkan wilayah yang tidak ditetapkan PSBB tidak dilakukan pembatasan untuk bekerja di tempat kerja.

Namun karena pandemi virus corona yang semakin meluas menyebabkan Presiden Joko Widodo menetapkan pandemi virus corona sebagai bencana nonalam melalui Keputusan Presiden R.I. No. 12 Tahun 2020, Penetapan Bencana Nonalam Penyebaran Corona Virus Disease 2019 (COVID-19). Menurut penulis, penetapan ini berdampak kepada pelaksanaan kontrak-kontrak kerja sama (termasuk perjanjian kerja) bahkan mungkin dapat dipergunakan sebagai alasan untuk menunda maupun memutuskan kontrak dengan alasan keadaan memaksa. Karena walaupun tidak ditetapkan PSBB, masyarakat akan cenderung membatasi kegiatannya di luar rumah.

\section{Penafsiran Sistematis Atas Ketentuan Pasal 154A Ayat (1) Huruf d UU Cipta Kerja Yang Mengatur Perusahaan Tutup Karena Keadaan Memaksa (force majeure)}

Ketentuan Pasal 164 Ayat (1) UU Ketenagakerjaan yang mengatur tentang pemutusan hubungan kerja karena alasan keadaan memaksa, telah dicabut oleh ketentuan Pasal 81 UU Cipta Kerja, dan diganti dengan ketentuan Pemutusan hubungan kerja karena alasan keadaan memaksa diatur dalam Pasal 154A Ayat (1) huruf d UU Cipta Kerja, yang berbunyi demikian "pemutusan hubungan kerja dapat terjadi karena alasan perusahaan tutup yang disebabkan keadaan memaksa (force majeure)"

Pembentuk undang-undang, tidak memberikan penjelasan dan batasanbatasan atas ketentuan Pasal 154A Ayat (1) huruf d UU Cipta Kerja. Bagian penjelasan dari ketentuan tersebut menyebutkan "cukup jelas", dan Peraturan pelaksana dari UU Cipta Kerja baru akan diterbitkan 3 (tiga) bulan semenjak undang-undang tersebut ditetapkan pada tanggal 2 November 2020. Karena itu saat ini terjadi kekosongan hukum, yang berpotensi menimbulkan permasalahan hukum dalam implementasinya. Misalnya, apakah perusahaan yang tutup, dan 
menerapkan kebijakan bekerja di rumah dapat dikategorikan perusahaan tutup sebagaimana dimaksud dalam Pasal 154A Ayat (1) huruf d UU Cipta Kerja, sehingga perusahaan boleh melakukan pemutusan hubungan kerja.

Oleh karena itu perlu dilakukan interpretasi hukum secara sistematis, untuk memperjelas maksud dari ketentuan Pasal 154A Ayat (1) huruf d UU Cipta Kerja. Menurut Mochtar Kusumaatmadja dan B. Arief Sidharta ${ }^{8}$ penafsiran sistematis adalah "Melakukan tafsir yang baik harus dilakukan secara sistematis, yakni berkaitan dengan ketentuan lain dalam teks undang-undang yang sama atau undang-undang lain yang bersangkutan atau ada kaitan dengan ketentuan yang sedang ditafsir."

Penulis melakukan interpretasi sistematis dengan mempergunakan ketentuan Kitab Undang-Undang Hukum Perdata, Staatsblad 1847 (selanjutnya disebut KUHPerdata), Pasal 1244, Pasal 1245, Pasal 1444, dan Pasal 1445, Putusan Mahkamah Konstitusi Nomor 19/PUU-IX/2011, doktrin, dan putusan-putusan pengadilan untuk memperjelas maksud dari Pasal 154A Ayat (1) huruf d UU Cipta Kerja. Pertama penulis akan menguraikan mengenai perusahaan tutup, kemudian menguraikan mengenai keadaan memaksa.

Majelis Hakim Konstitusi dalam pertimbangan perkara No. 19/PUUIX/2011 yang menguji ketentuan Pasal 164 Ayat (3) UU Ketenagakerjaan terhadap Undang-Undang Dasar 1945, menyatakan bahwa, dalam UU Ketenagakerjaan tidak ditemukan definisi yang jelas dan rigid atas frasa "perusahaan tutup". Apakah perusahaan tutup yang dimaksud adalah tutup secara permanen ataukah hanya tutup sementara. Adanya ketidakjelasan tersebut, telah menyebabkan siapa saja menafsirkan "perusahaan tutup" sesuai dengan kepentingannya sendiri, misalnya penutupan perusahaan sementara untuk renovasi merupakan bagian dari efisiensi dan menjadikannya sebagai dasar melakukan pemutusan hubungan kerja. Akibatnya terjadi ketidakpastian hukum bagi kelangsungan pekerjaan bagi pekerja/buruh di dalam menjalankan pekerjaannya.

8 Mochtar Kusumaatmadja dan B. Arief Sidharta, Pengantar Ilmu Hukum Suatu Pengantar Pertama Ruang Lingkup Berlakunya Ilmu Hukum Buku I, PT Alumni, Bandung, 2013, hlm., 102 
Guna menghindari ketidakpastian hukum tersebut, Majelis Hakim Konstitusi memberikan penjelasan, yang dimaksud perusahaan tutup harus dimaknai perusahaan tutup permanen atau perusahaan tutup tidak untuk sementara waktu. Menurut penulis, pendapat Majelis Hakim Konstitusi ini dapat dipergunakan untuk memperjelas makna perusahaan tutup dalam ketentuan Pasal 154A Ayat (1) huruf d UU Cipta Kerja.

Frasa "perusahaan tutup" dalam ketentuan Pasal 154A Ayat (1) huruf d UU Cipta Kerja haruslah dimaknai perusahaan tutup secara permanen. Hal ini juga sejalan dengan asas pemerataan hak dan kepastian hukum yang diatur dalam Pasal 2 UU Cipta kerja, dan juga sesuai dengan tujuan UU Cipta Kerja untuk menjamin setiap warga negara memperoleh pekerjaan, perlakuan yang adil dan layak dalam hubungan kerja.

Dengan demikian bila perusahaan tutup sementara, untuk memenuhi aturan PSBB yang ditetapkan oleh Pemerintah untuk mencegah penyebarluasan pandemi virus corona tidak dapat dijadikan alasan perusahaan untuk melakukan pemutusan hubungan kerja.

Selanjutnya penulis, akan menafsirkan mengenai keadaan memaksa Pasal 154A Ayat (1) huruf d UU Cipta Kerja dengan menggunakan teks undang-undang yang ada kaitannya, yaitu KUHPerdata. Definisi mengenai keadaan memaksa dalam KUHPerdata dapat ditemukan dalam ketentuan-ketentuan di bawah ini:

1 Pasal 1244 KUHPerdata "Debitur harus dihukum untuk mengganti biaya, kerugian dan bunga. bila ia tak dapat membuktikan bahwa tidak dilaksanakannya perikatan itu atau tidak tepatnya waktu dalam melaksanakan perikatan itu disebabkan oleh sesuatu hal yang tak terduga, yang tak dapat dipertanggungkan kepadanya. walaupun tidak ada itikad buruk kepadanya"

2 Pasal 1245 KUHPerdata “Tidak ada penggantian biaya. kerugian dan bunga bila karena keadaan memaksa atau karena hal yang terjadi secara kebetulan, debitur terhalang untuk memberikan atau berbuat sesuatu yang diwajibkan, atau melakukan suatu perbuatan yang terlarang baginya."

3 Pasal 1444 KUHPerdata "Jika barang tertentu yang menjadi pokok persetujuan musnah, tak dapat diperdagangkan, atau hilang hingga tak diketahui sama 
sekali apakah barang itu masih ada, atau tidak, maka hapuslah perikatannya, asal barang itu musnah atau hilang di luar kesalahan debitur dan sebelum ia lalai menyerahkannya. Bahkan meskipun debitur lalai menyerahkan suatu barang, yang sebelumnya tidak ditanggung terhadap kejadian-kejadian yang tak terduga, perikatan tetap hapus jika barang itu akan musnah juga dengan cara yang sama di tangan kreditur, seandainya barang tersebut sudah diserahkan kepadanya. Debitur diwajibkan membuktikan kejadian tak terduga yang dikemukakannya. Dengan cara bagaimanapun suatu barang hilang atau musnah, orang yang mengambil barang itu sekali-kali tidak bebas dan kewajiban untuk mengganti harga."

4 Pasal 1445 KUHPerdata "Jika barang yang terutang musnah, tak lagi dapat diperdagangkan, atau hilang di luar kesalahan debitur, maka debitur, jika ia mempunyai hak atau tuntutan ganti rugi mengenai barang tersebut, diwajibkan memberikan hak dan tuntutan tersebut kepada kreditur."

Dari ketentuan-ketentuan di atas, dapat ditarik suatu simpulan umum, bahwa keadaan memaksa adalah tidak dapat dilaksanakan suatu perikatan yang disebabkan adanya keadaan yang tidak terduga. Dalam hal terjadi suatu keadaan memaksa, maka tidak ada penggantian biaya, bunga dan kerugian. Untuk memperjelas definisi ini, penulis akan menyajikan beberapa pendapat ahli hukum, seperti di bawah ini:

1 Subekti9, "untuk dapat dikatakan suatu "keadaan memaksa" (overmacht atau force majeure), selain keadaan itu "di luar kekuasaannya" si berhutang dan "memaksa" keadaan yang telah timbul itu juga berupa suatu keadaan yang tidak dapat diketahui pada waktu perjanjian itu dibuat, setidak-tidaknya tidak dipikul resikonya oleh si berhutang."

2 Rahmat S.S. Soemadipradja ${ }^{10}$, "keadaan memaksa adalah suatu keadaan di mana salah satu pihak dalam suatu perikatan tidak dapat memenuhi seluruh atau sebagian kewajibannya sesuai apa yang diperjanjikan, disebabkan adanya

9 Subekti, Pokok-Pokok Hukum Perdata, PT Intermasa, Jakarta, 2001, hlm., 150.

10 Rahmat S.S. Soemadipradja, Penjelasan Hukum Tentang Keadaan Memaksa, PT Gramedia, Jakarta, 2010, hlm. 8. 
suatu peristiwa di luar kendali salah satu pihak yang tidak dapat diketahui atau tidak dapat diduga akan terjadi pada waktu membuat perikatan, di mana pihak yang tidak memenuhi kewajibannya ini tidak dapat dipersalahkan dan tidak harus menanggung risiko"

3 Purwahid Patrik ${ }^{11}$ keadaan memaksa adalah keadaan dimana debitur tidak melaksanakan prestasi karena tidak ada kesalahan maka akan berhadapan dengan keadaan memaksa yang tidak dapat dipertanggungjawabkan kepadanya.

Pendapat para ahli hukum di atas, memberikan gambaran yang lebih jelas bahwa keadaan memaksa adalah suatu keadaan, dimana salah satu pihak atau kedua pelah pihak dalam perikatan tidak dapat memenuhi kewajibannya berdasarkan perjanjian karena adanya suatu peristiwa yang di luar kendalinya. Pihak yang tidak memenuhi kewajibannya itu tidak dapat dipersalahkan dan tidak harus menanggung resiko.

Selanjutnya, Penulis akan menyajikan pertimbangan-pertimbangan hukum Mahkamah Agung R.I. yang menjelaskan penerapan keadaan memaksa dalam praktik.

Bagan 2: Putusan-Putusan Mahkamah Agung Terkait Keadaan Memaksa.

\begin{tabular}{|c|c|c|}
\hline No. & Perkara & Pertimbangan Majelis Hakim \\
\hline 1. & $2821 \mathrm{~K} / \mathrm{Pdt} / 2014$ & $\begin{array}{l}\text { Bahwa tenggelamnya kapal merupakan kecelakaan yang tidak } \\
\text { dapat diperkirakan atau dicegah, sehingga merupakan keadaan } \\
\text { darurat/overmacht; Bahwa Pasal } 468 \text { ayat (1) KUHD tidak dapat } \\
\text { digunakan dalam perkara ini karena telah diperoleh bukti } \\
\text { kejadian disebabkan force majeure berupa cuaca buruk }\end{array}$ \\
\hline 2. & 285 PK/Pdt /2010 & $\begin{array}{l}\text { In cassu Hakim telah melakukan kekhilafan/kekeliruan yang } \\
\text { nyata, dengan tidak mempertimbangkan bahwa perjanjian } \\
\text { kredit/perjanjian hutang piutang tersebut terjadi pada saat } \\
\text { krisis ekonomi yang melanda dunia yang berdampak pada } \\
\text { perekonomian Indonesia dan kondisi/situasi seperti ini } \\
\text { berdasarkan rasa keadilan seharusnya dipertimbangkan oleh } \\
\text { Judex Juris dalam memberikan perlindungan kepada Pemohon } \\
\text { Peninjauan Kembali }\end{array}$ \\
\hline 3. & 188 K/Pdt.Sus-PHI/2019 & $\begin{array}{l}\text { Bahwa oleh karena perusahaan Tergugat tutup bukan atas dasar } \\
\text { kehendak dari pihak Tergugat, akan tetapi sebagai akibat dari } \\
\text { adanya kejadian di luar kehendak/dugaan/kemampuan/kontrol }\end{array}$ \\
\hline
\end{tabular}

11 Id. 
yang tidak dapat dielakkan oleh Tergugat (musibah kebakaran)

yang berdampak menimbulkan kerugian besar bagi pihak Tergugat (force majeur)

4. 26 K/Pdt.Sus-PHI/2018 Bahwa terjadinya Pemutusan Hubungan Kerja disebabkan Ijin Usaha Operasional Perkebunannya dicabut oleh Pejabat berwenang yaitu Bupati Parigi Mountong pada tanggal 20 Desember 2013, sehingga perusahaan tidak beroperasi (force majeur)

Sumber: Direktori Putusan Mahkamah Agung R.I.

Berdasarkan putusan-putusan Mahkamah Agung R.I. di atas, terdapat beberapa contoh keadaan memaksa adalah: krisis ekonomi dunia, kecelakaan yang tidak dapat dicegah, pencabutan izin usaha, dan kebakaran.

Berdasarkan ketentuan Pasal 1244, 1245, 1444, 1445 KUHPerdata, pendapat-pendapat ahli dan putusan-putusan Mahkamah Agung R.I. dapat ditarik suatu simpulan umum, yang dimaksud dengan keadaan memaksa adalah salah satu pihak dalam perjanjian tidak dapat memenuhi sebagian atau seluruh kewajibannya yang telah diperjanjikan karena terjadi suatu peristiwa yang berada diluar kendalinya yang tidak dapat diperkirakan pada saat dibuatnya perjanjian, sehingga pihak tersebut tidak dapat dimintai pertanggungjawaban dan tidak harus menanggung resiko.

Dengan demikian, dari ketentuan Pasal 154A Ayat (1) huruf d UU Cipta Kerja dapat dibuat suatu simpulan:

1 Perusahaan harus tutup secara permanen; dan

2 Pengusaha dan/atau Pekerja/buruh yang berada dalam hubungan kerja tidak dapat memenuhi sebagian atau seluruh kewajibannya sebagaimana diatur dalam perjanjian kerja karena terjadi suatu peristiwa yang berada diluar kendalinya yang tidak dapat diperkirakan pada saat dibuatnya perjanjian kerja sehingga pihak tersebut tidak dapat dimintai pertanggungjawaban dan tidak harus menanggung resiko

\section{Pandemi Virus Corona Sebagai Alasan Untuk Melakukan Pemutusan Hubungan Kerja Dengan Alasan Keadaan Memaksa Sebagaimana Dimaksud Dalam Pasal 154A Ayat (1) huruf d UU Cipta Kerja}




\section{Perusahaan Harus Tutup secara Permanen}

Pasal 154A Ayat (1) huruf d UU Cipta Kerja, mensyaratkan perusahaan harus tutup dengan disebabkan keadaan memaksa. Berdasarkan ketentuan ini, berarti bila:

1. Perusahaan tutup bukan karena keadaan memaksa;

2. Terjadi keadaan memaksa, namun perusahaan tidak tutup;

Maka tidak dapat dilakukan pemutusan hubungan kerja dengan alasan keadaan memaksa.

2. Pengusaha dan/atau Pekerja/buruh yang berada dalam hubungan kerja tidak dapat memenuhi sebagian atau seluruh kewajibannya sebagaimana diatur dalam perjanjian kerja karena terjadi suatu peristiwa yang berada diluar kendalinya yang tidak dapat diperkirakan pada saat dibuatnya perjanjian kerja sehingga pihak tersebut tidak dapat dimintai pertanggungjawaban dan tidak harus menanggung resiko

Pandemi virus corona merupakan suatu kondisi yang tidak dapat diperkirakan pada saat dibuatnya perjanjian kerja, semenjak bulan Maret 2020 hingga saat ini terus terjadi penambahan orang yang dinyatakan positif virus corona. Pandemi ini telah menjadi suatu bencana nasional nonalam dan berdampak pada pelaksanaan kegiatan usaha. Namun dampak yang ditimbulkan bermacam-macam, ada usaha yang berdampak tinggi (high impact) sehingga perusahaan tidak dapat melakukan usahanya sama sekali atau terpaksa harus menutup usahanya, ada jenis usaha yang berdampak rendah (low impact) dan bahkan mendapatkan keuntungan.

ILO $^{12}$ mengelompokan industri-industri yang terdampak pandemi virus corona.

12 International Labour Organization (ILO), ILO Monitor: COVID-19 And The World Of Work. Third Edition Updated Estimates And Analysis, https://www.ilo.org/wcmsp5/groups/public/--dgreports/---dcomm/documents/briefingnote/wcms_743146.pdf, terakhir diakses 20 Mei, 2020. 
Bagan 3: Industri yang terdampak pandemi virus corona.

\begin{tabular}{llcc}
\hline No. & \multicolumn{1}{c}{ Economic Sector } & $\begin{array}{c}\text { Impact of crisis on } \\
\text { economic output }\end{array}$ & $\begin{array}{c}\text { Employers } \\
\text { (millions) }\end{array}$ \\
\hline $\mathbf{1}$ & $\begin{array}{l}\text { Wholesale and retail trade; repair of motor vehicles } \\
\text { and motorcycles }\end{array}$ & High & 21 \\
\hline $\mathbf{2}$ & Manufacturing & High & 12 \\
\hline $\mathbf{3}$ & Accommodation and food services & High & 7 \\
\hline $\mathbf{4}$ & Real estate; business and administrative activities & High & 7 \\
\hline $\mathbf{5}$ & Human health and social work activities & Low & 21 \\
\hline $\mathbf{6}$ & Education & Low & 1 \\
\hline $\mathbf{7}$ & Utilities & Low & $<1$ \\
\hline $\mathbf{8}$ & $\begin{array}{l}\text { Public administration and defence; compulsory social } \\
\text { security }\end{array}$ & Low & $<1$ \\
\hline Sumber: ILO Monitor: COVID-19 and the world of work. Third edition Updated estimates and analysis
\end{tabular}

Sebagai contoh, usaha perhotelan, saat ini telah terdapat 1.642 hotel $^{13} \mathrm{di}$ seluruh Indonesia yang berhenti beroperasi karena terdampak pandemi virus corona dan diperkirakan terdapat 150.000 orang karyawan ${ }^{14}$ yang tekena dampak dari penghentian operasi ini. Adanya penghentian operasi atau penutupan usaha seperti contoh di atas telah menyebabkan karyawan tidak dapat melakukan kewajibannya sebagaimana diatur dalam perjanjian kerja setidak-tidaknya hingga pandemi virus corona berakhir.

Namun ada usaha-usaha yang justru terkena dampak rendah bahkan mendapatkan keuntungan, misalnya usaha-usaha di bidang farmasi, masker, jasa logistik, dan telekomunikasi ${ }^{15}$.

Perbedaan kondisi seperti contoh-contoh di atas menunjukkan perlu dilakukan analisa kasus per kasus untuk menentukan apakah dapat dilakukan PHK karena alasan pandemi virus corona, tidak dapat dilakukan penyamarataan

13 Kontan.co.id, Ratusan hotel di Jabar, Bali, Jatim dan DKI Tutup Gara-Gara Corona, https://industri.kontan.co.id/news/ratusan-hotel-di-jabar-bali-jatim-dan-dki-tutup-gara-garacorona, terakhir diakses 5 Mei, 2020.

14 Republika.co.id, Covid-19 Tutup 1.266 Hotel di Indonesia, https://republika.co.id/berita/q8elx3328/covid19-tutup-1266-hotel-di-indonesia terakhir diakses 5 Mei, 2020.

15 Vivanews, Terdampak Corona, 6 Perusahaan Ini Justru Paling Untung di Tengah Pandemi, https://www.vivanews.com/sindikasi/44560-terdampak-corona-6-perusahaan-ini-justrupaling-untung-di-tengah-pandemi?medium=autonextterakhir, diakses 21 Mei, 2020. 
karena pasti menimbulkan kekacauan dan ketidakadilan. Untuk perusahaan yang terdampak besar opsi melakukan PHK karena alasan keadaan memaksa menjadi dapat dipahami. Sebaliknya perusahaan yang terdampak kecil opsi PHK karena alasan keadaan memaksa tidak beralasan. Mengingat kewajiban-kewajiban masih dapat dilakukan walaupun terbatas. (misalnya pekerjaan dilakukan di rumah). Kalaupun pengusaha dan/atau Pekerja/buruh tidak dapat melakukan kewajibannya itu hanya bersifat "menunda" pelaksanaan kewajiban hingga pandemi virus corona telah berakhir (walaupun belum diketahui waktu pastinya).

Sebagai konsekuensi dari adanya pandemi virus corona yang berada diluar kemampuan dari pengusaha dan Pekerja/buruh maka pihak-pihak dalam perjanjian kerja tidak dapat dimintai pertanggungjawaban dan tidak harus menanggung risiko yang ditimbulkan dari adanya keadaan memaksa tersebut. Namun karena dampak pandemi ini nyata, perlu pemikiran strategis untuk memitigasi risiko untuk keberlangsungan usaha dan menjadi jaminan keamanan ekonomi dan sosial bagi seluruh stakeholders.

\section{Apakah terdapat alternatif yang dapat diambil oleh pengusaha, Pekerja/buruh, dan pemerintah untuk mencegah terjadinya PHK karena adanya pandemi virus corona}

PHK merupakan suatu peristiwa yang tidak diharapkan terjadinya, khususnya dari kalangan buruh/pekerja karena dengan PHK buruh/pekerja yang bersangkutan akan kehilangan mata pencaharian untuk menghidupi diri dan keluarganya, karena itu semua pihak yang terlibat dalam hubungan industrial dengan segala upaya harus mengusahakan jangan terjadi pemutusan hubungan kerja16. Dalam ketentuan Pasal 151 ayat (1) UU Cipta Kerja diatur sebagai berikut "Pengusaha, pekerja/buruh, serikat pekerja/serikat buruh, dan pemerintah, harus mengusahakan agar tidak terjadi pemutusan hubungan kerja."

Penjelasan dari Pasal 151 ayat (1) UU Cipta Kerja menjelaskan sebagai berikut "Yang dimaksud dengan mengupayakan adalah kegiatan-kegiatan yang

16 Lalu Husni, Pengantar Hukum Ketenagakerjaan Indonesia, PT. RajaGrafindo Persada, Jakarta, 2000, hlm.177. 
positif yang pada akhirnya dapat menghindari terjadinya pemutusan hubungan kerja antara lain pengaturan waktu kerja, penghematan, pembenahan metode kerja, dan memberikan pembinaan kepada pekerja/buruh."

Dalam ketentuan Pasal 151 ayat (1) UU Cipta Kerja dan penjelasannya terdapat 3 (tiga) prinsip yang dapat dijadikan dasar untuk mengambil keputusan bersama antara pemerintah, pengusaha dan Pekerja/buruh di tengah pandemi virus corona:

Prinsip Pertama, PHK merupakan upaya terakhir yang diambil pengusaha. Hal ini beralasan karena PHK berdampak sangat besar kepada kesejahteraan Pekerja/buruh beserta keluarganya. Dengan demikian walaupun saat ini kondisi perekonomian sedang buruk akibat pengaruh pandemi virus corona, namun PHK harus tetap menjadi upaya terakhir yang diambil oleh pengusaha.

Prinsip Kedua, sebelum mengambil keputusan untuk melakukan PHK dengan alasan keadaan memaksa akibat pandemi virus corona, pemerintah, pengusaha dan Pekerja/buruh harus melakukan kegiatan-kegiatan yang positif untuk mencegah dilakukan PHK. Penggunaan kata "harus" artinya bersifat imperatif, jika tidak dilakukan akan berakibat PHK tersebut menjadi cacat formil.

Kegiatan-kegiatan positif yang diharuskan oleh pembentuk perundangundangan antara lain adalah pengaturan waktu kerja, penghematan, pembenahan metode kerja, dan memberikan pembinaan kepada pekerja/buruh. Penggunaan kata "antara lain” artinya selain hal-hal yang diatur dalam ketentuan Pasal 151 Ayat (1) UU Ketenagakerjaan boleh dilakukan upaya-upaya lain untuk mencegah terjadinya PHK.

Prinsip Ketiga, adalah hubungan kooperatif antara pengusaha, pekerja/buruh, serikat pekerja/serikat buruh, dan pemerintah. Hal ini juga dijelaskan pada bagian penjelasan umum UU Ketenagakerjaan yang berbunyi: "Pembangunan ketenagakerjaan harus diatur sedemikian rupa sehingga terpenuhi hak-hak dan perlindungan yang mendasar bagi tenaga kerja dan pekerja/buruh serta pada saat yang bersamaan dapat mewujudkan kondisi yang kondusif bagi pengembangan dunia usaha." 
Hubungan kooperatif menurut Mohammad Hatta ${ }^{17}$ disokong oleh "pengakuan bahwa setiap anggota masyarakat sebagai individu yang mandiri dan otonom, dan relasi antarindividu otonom itu menampilkan solidaritas dan sikap suka rela untuk siap saling membantu (mutual assistance atau gotong royong). Sikap suka rela untuk saling mendukung mendapat perhatian penting dalam gagasan masyarakat kooperatif. Sikap suka rela menunjukkan bahwa pelakunya adalah individu yang mandiri dan menunjukkan tanggungjawab sosial terhadap kelompoknya. Tujuan dari sikap ini adalah partisipasi aktif untuk saling mendukung baik di bidang politik dan ekonomi."

Dalam kondisi yang sulit seperti sekarang ini perlu ada sikap kesukarelaan dari pengusaha, Pekerja/buruh, dan pemerintah untuk saling membantu. Sangatlah tidak adil bila seluruh bebannya ditimpakan kepada salah satu pihak, misalnya pengusaha diminta tetap membayarkan upah Pekerja/buruh secara penuh walaupun usaha ditutup sama sekali, atau Pekerja/buruh langsung di PHK padahal perusahaan termasuk dalam katergori terdampak rendah (low impact).

Hubungan kooperatif atau gotong royong juga bisa berarti ada hak masingmasing yang dikurangi dalam batas yang wajar dan memperhatikan kesejahteraan minimal dari masing-masing pihak untuk tujuan bersama berupa usaha yang tetap dapat berjalan dan menjadikan PHK sebagai upaya yang terakhir.

Bentuk partisipasi antara pemerintah, pengusaha, dan Pekerja/buruh yang dapat dilakukan adalah:

Pemerintah memiliki peran strategis menentukan kebijakan-kebijakan untuk melindungi pengusaha dalam menjalankan usahanya di tengah pandemi virus corona dan menjamin kelangsungan kerja dari Pekerja/buruh. Pemerintah juga berfungsi sebagai pengawas (Pasal 102 UU Ketenagakerjaan) dan sebagai mediator (Undang-Undang R.I. No. 2 Tahun 2004, Penyelesaian Perselisihan Hubungan Industrial, L.N.R.I. 2004 Pasal 8) manakala terjadi sengketa. Menurut John W. Head, “dalam mediasi ada seseorang bertindak sebagai "kendaraan” untuk berkomunikasi antara pihak sehingga pandangan mereka yang berbeda atas

17 Pusat Studi Pancasila Universitas Katolik Parahyangan, Kanisius, Yogyakarta, 2012, hlm. 211212. 
sengketa tersebut dapat dipahami dan mungkin didamaikan, tetapi tanggung jawab utama tercapainya suatu perdamaian tetap di tangan para pihak sendiri18." Artinya Pemerintah menjembatani komunikasi antara pengusaha dan Pekerja/buruh untuk mencegah terjadinya PHK melalui mediasi. Pemerintah juga dapat secara berkala melakukan pengawasan terhadap hubungan kerja, untuk memastikan jalannya usaha dan kelangsungan pekerjaan dari Pekerja/buruh.

Pengusaha berperan sebagai inisiator untuk membangun komunikasi dengan Pekerja/buruh, untuk membicarakan secara terbuka mengenai kondisi perusahaan dan komitmen untuk mencegah terjadinya PHK, melakukan kegiatankegiatan positif misalnya melakukan pengaturan waktu kerja, penambahan metode kerja, dan memberikan pembinaan kerja kepada Pekerja/buruh.

Hubungan kooperatif dimulai dengan komunikasi. Menurut Gerald S Nirenberg19 "kesediaan untuk bekerja sama adalah percakapan, bisa terwujud saat Anda menunjukkan bahwa Anda merasa gagasan dan perasaan orang yang anda ajak bicara sama pentingnya dengan gagasan dan perasaan Anda.” Komunikasi menjembatani kepentingan pengusaha dan Pekerja/buruh.

Beberapa kegiatan-kegiatan positif yang dapat dibicarakan dan disepakati bersama, misalnya:

(1) mengurangi waktu dan jam kerja perusahaan, pengurangan waktu dan jam kerja ini dapat mengurangi biaya yang dikeluarkan oleh perusahaan untuk kegiatan operasional perusahaan ${ }^{20}$;

(2) menawarkan kemungkinan, bagi Pekerja/buruh untuk mengambil cuti di luar tanggungan perusahaan (unpaid leave) sebagaimana dimaksud dalam Pasal 93 Ayat (1) UU Ketenagakerjaan;

(3) menawarkan kemungkinan, bagi Pekerja/buruh untuk mengurangi upah yang akan diterimanya dan/atau cara pembayarannya dengan catatan harus

18 Frans Hendra Winarta, Hukum Penyelesaian Sengketa Arbitrase Nasional Indonesia dan Internasional, Sinar Grafika, Jakarta, 2020, hlm 15-16.

19 Dale Carnegie \& Associate, How To Win Friends \& Influence People In The Digital Age, Gramedia, Jakarta, 2019, hlm 167.

20 Atta Tarki, Paul Levy dan Jeff Weiss, The Coronavirus Crisis Doesn't Have to Lead to Layoffs, https://hbr.org/2020/03/the-coronavirus-crisis-doesnt-have-to-lead-to-layoffs, terakhir diakses 20 Mei, 2020. 
memperhatikan kebutuhan hidup layak Pekerja/buruh sebagaimana diatur dalam Peraturan Pemerintah R.I. No. 78 Tahun 2015, Pengupahan L.N.R.I 2015 jo. Surat Edaran Menteri Ketenagakerjaan R.I. No. M/3/HK.04/III/2020 tentang Pelindungan Pekerja/Buruh dan Kelangsungan Usaha dalam Rangka Pencegahan dan Penanggulangan COVID-19 Butir II Angka 4. Misalnya disepakati upah yang diterima Pekerja/buruh adalah 75\% upah pokok sedangkan komponen berupa tunjangan tetap ditangguhkan terlebih dahulu pembayarannya.

(4) mengalihkan fungsi pekerja dari fungsi yang tidak dapat berjalan pada saat pandemi virus corona ke fungsi yang membutuhkan tenaga ekstra. Misalnya yang dilakukan penerbangan Air Asia yang kehilangan pendapatannya karena 96\% penerbangan dihentikan karena pandemi virus corona, untuk menghindari PHK maka Air Asia mengalihkan 1.800 karyawan dari fungsi yang berbeda untuk membantu customer support ${ }^{21}$.

(5) membagi karyawan dalam group-group kemudian mengatur waktu kerjanya dalam bentuk giliran (shift) kerja. Misalnya yang dilakukan oleh PT. INKA (Persero) membagi karyawan menjadi 2 (dua) group.

Shift 1 pada pukul 06.30 - 14.30 WIB, dan Shift 2 pada pukul $14.30-22.30$ $\mathrm{WIB}^{22}$. Adanya pembagian shift berarti perusahaan tetap dapat menjalankan usahanya sekaligus menegikuti anjuran Permenkes Pedoman PSBB untuk melakukan pekerjaan dengan jumlah minimum karyawan.

(6) Secara kreatif, mengubah arahan bisnis. Misalnya pada bidang manufaktur, mengubah produk selama didukung oleh infrastruktur yang sudah ada dan material yang tersedia, misalnya UMKM konfeksi yang membuat tas, dompet diubah menjadi pembuat alat pelindung diri23.

21 Tony Fernandes, A message from Tony, https://newsroom.airasia.com/news/a-message-fromtony, terakhir diakses 20 Mei, 2020.

22 DetikFinance, Sederet Respons BUMN Soal Skema New Normal Erick Thohir, https://finance.detik.com/berita-ekonomi-bisnis/d-5020168/sederet-respons-bumn-soalskema-new-normal-erick-thohir/1, terakhir diakses 20 Me,i 2020.

23 Unair News, Ubah Bisnis Konfeksi jadi Produsen Baju APD untuk Bantu Tangani Covid-19, http://news.unair.ac.id/2020/04/13/ubah-bisnis-konfeksi-jadi-produsen-baju-apd-untukbantu-tangani-covid-19/ terakhir diakses 21 Mei, 2020. 
Pekerja/buruh juga memiliki peran penting, misalnya dengan (1) berpartisipasi untuk memberikan masukan-masukan kepada pengusaha dan pemerintah; (2) mempergunakan hak unpaid leave (yang diusulkan oleh pengusaha); dan (3) menerima kemungkinan adanya pemotongan upah atau perubahan cara membayar upah yang diusulkan oleh pengusaha.

Karena hubungan kerja antara pengusaha dan Pekerja/buruh lahir karena adanya perjanjian kerja yang mengikat sebagai undang-undang bagi pembuatnya (pacta sunt servanda) dan tidak dapat diubah secara sepihak ${ }^{24}$, maka sesuai dengan ketentuan Pasal 55 UU Ketenagakerjaan jo. Pasal 1338 KUHPerdata, yang berbunyi:

Pasal 55 UU Ketenagakerjaan "Perjanjian kerja tidak dapat ditarik kembali dan/atau diubah, kecuali atas persetujuan para pihak."

Pasal 1338 KUHPerdata "Semua persetujuan yang dibuat sesuai dengan undangundang berlaku sebagai undang-undang bagi mereka yang membuatnya. Persetujuan itu tidak dapat ditarik kembali selain dengan kesepakatan kedua belah pihak, atau karena alasan-alasan yang ditentukan oleh undang-undang. Persetujuan harus dilaksanakan dengan itikad baik."

Perubahan-perubahan yang disepakati antara pengusaha dan Pekerja/buruh harus dituangkan dalam perubahan perjanjian kerja agar mengikat bagi para pihak dalam perjanjian kerja. Menuangkan kesepakatan-kesepakatan dalam bentuk tertulis juga akan mempermudah pelaksanaannya serta menghindari terjadinya perselisihan antara pihak-pihak dalam perjanjian kerja.

\section{Penutup}

Melalui penafsiran sistematis, diperoleh pengertian keadaan memaksa menurut Pasal 154A Ayat (1) huruf d UU Cipta Kerja yaitu:

1 Perusahaan tutup secara permanen; dan

2 Pengusaha dan/atau Pekerja/buruh yang berada dalam hubungan kerja tidak dapat melakukan sebagian atau seluruh kewajibannya sebagaimana diatur

24 Mariam Darus Badrulzaman, Hukum Perikatan Dalam KUH Perdata Buku Ketiga, Citra Aditya Bakti, Bandung, 2015, hlm 123. 
dalam perjanjian kerja karena terjadi suatu peristiwa yang berada di luar kendalinya yang tidak dapat diperkirakan pada saat dibuatnya perjanjian kerja, sehingga pihak tersebut tidak dapat dimintai pertanggungjawaban dan tidak harus menanggung resiko.

Pandemi virus corona tidak serta merta dapat dijadikan alasan untuk melakukan pemutusan hubungan kerja, karena Pasal 154A Ayat (1) huruf d UU Cipta Kerja memberikan syarat berupa keadaan memaksa yang terjadi telah menyebabkan perusahaan tutup secara permanen.

Perusahaan-perusahaan yang mengalami kerugian yang besar (high impact) maupun yang mengalami dampak kecil (low impact) dari pandemi virus corona, perlu melakukan berbagai usaha agar usahanya dapat tetap berjalan, dan kegiatan-kegiatan yang positif untuk mencegah terjadinya PHK.

Dari ketentuan Pasal 151 ayat (1) UU Cipta Kerja dapat ditemukan prinsipprinsip: (1) PHK merupakan upaya yang terakhir walaupun saat ini kondisi perekonomian sedang buruk akibat pandemi virus corona; (2) Sebelum melakukan PHK, pemerintah, pengusaha dan Pekerja/buruh harus melakukan kegiatan-kegiatan positif untuk mencegah terjadi PHK; (3) Hubungan kooperatif atau gotong royong antara pengusaha, Pekerja/buruh, dan pemerintah di tengah kondisi yang sulit karena pandemi virus corona.

Hubungan kooperatif yang dilakukan, adalah pemerintah berperan untuk menetapkan kebijakan-kebijakan, pengawasan dan mediasi untuk mencegah terjadinya PHK. Pengusaha dengan melakukan kegiatan-kegiatan positif misalnya mengurangi upah dan fasilitas pimpinan perusahaan seperti direktur dan manajer, mengurangi waktu kerja dan jam kerja perusahaan. Sedangkan untuk Pekerja/buruh dengan memberikan masukan-masukan kepada pengusaha, mempergunakan hak unpaid leave, dan menerima kemungkinan adanya pemotongan upah atau perubahan cara membayar upah yang diusulkan oleh pengusaha asalkan tetap memperhatikan kebutuhan hidup layak Pekerja/buruh.

Kesepakatan yang dibaut antara Pengusaha dengan Pekerja/buruh dalam rangka untuk menjaga kelangsungan usaha dan keberlangsungan kerja, misalnya dengan mempergunakan hak unpaid leave atau pemotongan upah atau perubahan 
cara membayar upah dituangkan dalam bentuk perjanjian tertulis sesuai dan dengan memperhatikan ketentuan Pasal 1338 KUHPerdata. Tujuannya perubahanperubahan dilakukan secara tertulis, agar mempermudah pelaksanaannya serta menghindari terjadinya perselisihan antara pihak-pihak dalam perjanjian kerja.

\section{Daftar Pustaka}

\section{Buku:}

Dale Carnegie \& Associate, How To Win Friends \& Influence People In The Digital Age, Gramedia, Jakarta, 2019.

Frans Hendra Winarta, Hukum Penyelesaian Sengketa Arbitrase Nasional Indonesia dan Internasional, Sinar Grafika, Jakarta, 2020.

Lalu Husni, Pengantar Hukum Ketenagakerjaan Indonesia, Edisi Revisi, PT. RajaGrafindo Persada, Jakarta, 2000.

Mariam Darus Badrulzaman, Hukum Perikatan Dalam KUH Perdata Buku Ketiga, Citra Aditya Bakti, Bandung, 2015.

Mochtar Kusumaatmadja dan B. Arief Sidharta, Pengantar Ilmu Hukum Suatu Pengantar Pertama Ruang Lingkup Berlakunya Ilmu Hukum Buku I, PT Alumni Bandung, 2013.

Pusat Studi Pancasila Universitas Katolik Parahyangan, Kanisius, Yogyakarta, 2012.

Rahmat S.S. Soemadipradja, Penjelasan Hukum tentang Keadaan Memaksa, PT Gramedia, Jakarta, 2010.

Subekti, Pokok-Pokok Hukum Perdata, PT Intermasa, Jakarta, 2001.

\section{Web Dokumen:}

Atta Tarki, Paul Levy dan Jeff Weiss, The Coronavirus Crisis Doesn't Have to Lead to Layoffs, https://hbr.org/2020/03/the-coronavirus-crisis-doesnt-have-tolead-to-layoffs (terakhir diakses 20 Mei 2020).

Bank Indonesia, Laporan Perekonomian Indonesia 2019, hlm. 28, https://www.bi.go.id/en/ruang-media/info-terbaru/Pages/Buku-LaporanPerekonomian-2019-Sinergi-Kunci-Utama-Menjaga-Perekonomian-diTengah-Pandemi-Covid-19.aspx (terakhir diakses 16 April 2020).

CNBCIndonesia.com, Corona Makan Korban: 1,2 Juta Pekerja Kena PHK dan Dirumahkan, https://www.cnbcindonesia.com/news/2020040919003916-151007/corona-makan-korban-12-juta-pekerja-kena-phk-dandirumahkan, (terakhir diakses 20 Mei 2020). 
CNBC Indonesia, Ini Daerah Asal \& Tujuan yang Terkunci untuk Aktivitas Mudik https://www.cnbcindonesia.com/news/20200424200534-4-154348/inidaerah-asal-tujuan-yang-terkunci-untuk-aktivitas-mudik (terakhir diakses 5 Mei 2020).

CNNIndonesia.com, Sri Mulyani Sebut Dampak Virus Corona Melebihi Krisis 1998, https://www.cnnindonesia.com/ekonomi/20200406193647-532-

490944/sri-mulyani-sebut-dampak-virus-corona-melebihi-krisis-1998, (terakhir diakses 16 April 2020).

DetikFinance, Sederet Respons BUMN Soal Skema New Normal Erick Thohir https://finance.detik.com/berita-ekonomi-bisnis/d-5020168/sederetrespons-bumn-soal-skema-new-normal-erick-thohir/1 (terakhir diakses 20 Mei 2020).

Gugus Tugas Percepatan Penanganan COVID19, Peta Sebaran, https://www.covid19.go.id/situasi-virus-corona/, (terakhir diakses 19 Mei 2020).

International Labour Organization (ILO), Covid 19: Mendorong kebutuhan ekonomi dan ketenagakerjaan ILO: COVID-19 Sebabkan Kehilangan Besar dalam Jam Kerja dan Pekerjaan, https://www.ilo.org/jakarta/info/public/pr/WCMS_741127/lang-en/index.htm, (terakhir diakses 20 Mei 2020).

International Labour Organization (ILO), ILO Monitor: COVID-19 and the world of work. Third edition Updated estimates and analysis 2020, https://www.ilo.org/wcmsp5/groups/public/---dgreports/--dcomm/documents/briefingnote/wcms_743146.pdf (terakhir diakses 20 Mei 2020).

Kontan.co.id, Ratusan hotel di Jabar, Bali, Jatim dan DKI tutup gara-gara corona, https://industri.kontan.co.id/news/ratusan-hotel-di-jabar-bali-jatim-dandki-tutup-gara-gara-corona, (terakhir diakses 5 Mei 2020).

Natalie Blyth, How Companies Can Build Resilience Against Pandemics, https://www.weforum.org/agenda/2020/04/how-companies-buildresilience-against-pandemics/ (terakhir diakses 20 Mei 2020).

Republika.co.id, Covid-19 Tutup 1.266 Hotel di Indonesia https://republika.co.id/berita/q8elx3328/covid19-tutup-1266-hotel-diindonesia (terakhir diakses 5 Mei 2020).

Tony Fernandes, A message from Tony, https://newsroom.airasia.com/news/amessage-from-tony (terakhir diakses 20 Mei 2020).

Unair News, Ubah Bisnis Konfeksi jadi Produsen Baju APD untuk Bantu Tangani Covid-19, http://news.unair.ac.id/2020/04/13/ubah-bisnis-konfeksi-jadiprodusen-baju-apd-untuk-bantu-tangani-covid-19/ (terakhir diakses 21 Mei 2020).

Vivanews, Terdampak Corona, 6 Perusahaan Ini Justru Paling Untung di Tengah Pandemi, https://www.vivanews.com/sindikasi/44560-terdampakcorona-6-perusahaan-ini-justru-paling-untung-di-tengahpandemi?medium=autonext (terakhir diakses 21 Mei 2020). 


\section{Peraturan Perundang-Undangan:}

Kitab Undang-Undang Hukum Perdata, Staatsblad 1847.

Undang-Undang R.I, No 13 Tahun 2003, Ketenagakerjaan, L.N.R.I Tahun 2003.

Undang-Undang R.I. No. 2 Tahun 2004, Penyelesaian Perselisihan Hubungan Industrial, L.N.R.I. 2004.

Undang-Undang R.I, Nomor 6 Tahun 2018, Kekarantinaan Kesehatan, L.N.R.I. Tahun 2018.

Peraturan Pemerintah R.I. No. 78 Tahun 2015, Pengupahan L.N.R.I 2015.

Peraturan Pemerintah R.I. Nomor 21 Tahun 2020, Pembatasan Sosial Berskala Besar Dalam Rangka Percepatan Penanganan Corona Virus Disease 2019 (Covid-19), L.N.R.I 2020.

Keputusan Presiden R.I. No. 11 Tahun 2020, Penetapan Kedaruratan Kesehatan Masyarakat Corona Virus Disease 2019 (COVID-19).

Keputusan Presiden R.I. No. 12 Tahun 2020, Penetapan Bencana Nonalam Penyebaran Corona Virus Disease 2019 (COVID-19).

Peraturan Menteri Kesehatan R.I. No. 9 Tahun 2020, Pedoman Pembatasan Sosial Berskala Besar Dalam Rangka Percepatan Penanganan Corona Virus Disease 2019 (COVID-19), B.N.R.I. 2020.

Surat Edaran Menteri Ketenagakerjaan R.I. No. M/3/HK.04/III/2020 tentang Pelindungan Pekerja/Buruh dan Kelangsungan Usaha dalam Rangka Pencegahan dan Penanggulangan COVID-19.

\section{Putusan Pengadilan:}

Putusan Mahkamah Agung R.I. No. 285 PK/Pdt /2010.

Putusan Mahkamah Agung R.I. No. 2821 K/Pdt/2014.

Putusan Mahkamah Agung R.I. No. 26 K/Pdt.Sus-PHI/2018.

Putusan Mahkamah Agung R.I. No.188 K/Pdt.Sus-PHI/2019.

\section{Putusan Mahkamah Konstitusi:}

Putusan Mahkamah Konstitusi No. 19/PUU-IX/2011 